\title{
Products of in Situ Corrosion of Depleted Uranium Ammunition in Bosnia and Herzegovina Soils
}

\author{
Yuheng Wang, ${ }^{\dagger}$ Konstantin von Gunten, ${ }^{\dagger}$ Barbora Bartova, ${ }^{\dagger}$ Nicolas Meisser, ${ }^{\ddagger}$ Markus Astner, ${ }^{\S}$ \\ Mario Burger, ${ }^{\S}$ and Rizlan Bernier-Latmani* ${ }^{\dagger} \dagger$ \\ ${ }^{\dagger}$ Ecole Polytechnique Fédérale de Lausanne (EPFL), Environmental Microbiology Laboratory (EML), EPFL-ENAC-IIE-EML, \\ Station 6, CH-1015 Lausanne, Switzerland \\ ${ }^{\ddagger}$ Musée cantonal de géologie, Université de Lausanne, CH-1015 Lausanne, Switzerland \\ ${ }^{\S}$ Federal Office for Civil Protection, Spiez Laboratory, Physics Division, CH-3700 Spiez, Switzerland
}

Supporting Information

ABSTRACT: Hundreds of tons of depleted uranium (DU) ammunition were used in previous armed conflicts in Iraq, Bosnia and Herzegovina, and Serbia/Kosovo. The majority $(>90 \%)$ of DU penetrators miss their target and, if left in the environment, corrode in these postconflict zones. Thus, the best way to understand the fate of bulk DU material in the environment is to characterize the corrosion products of intact DU penetrators under field conditions for extended periods of time. However, such studies are scarce. To fill this knowledge gap, we characterized corrosion products formed from two intact DU penetrators that remained in soils in Bosnia and Herzegovina for over seven years. We used a combination of X-ray powder diffraction, electron microscopy, and X-ray absorption spectroscopy. The results show that metaschoepite $\left(\mathrm{UO}_{3}\left(\mathrm{H}_{2} \mathrm{O}\right)_{2}\right)$ was a

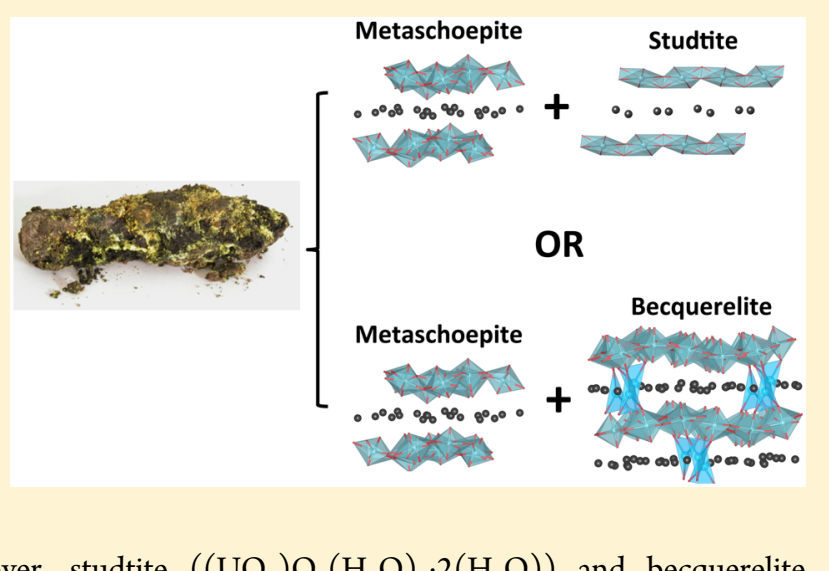
main component of the two DU corrosion products. Moreover, studtite $\left(\left(\mathrm{UO}_{2}\right) \mathrm{O}_{2}\left(\mathrm{H}_{2} \mathrm{O}\right)_{2} \cdot 2\left(\mathrm{H}_{2} \mathrm{O}\right)\right)$ and becquerelite $\left(\mathrm{Ca}\left(\mathrm{UO}_{2}\right)_{6} \mathrm{O}_{4}(\mathrm{OH})_{6} \cdot 8\left(\mathrm{H}_{2} \mathrm{O}\right)\right)$ were also identified in the corrosion products. Their formation through transformation of metaschoepite was a result of the geochemical conditions under which the penetrators corroded. Moreover, we propose that the transformation of metaschoepite to becquerelite or studtite in the DU corrosion products would decrease the potential for mobilization of $U$ from corroded DU penetrators exposed to similar environments in postconflict areas.

\section{INTRODUCTION}

Depleted uranium (DU), a byproduct of nuclear fuel production, is used to manufacture armor-piercing ammunition, due to its high density, pyrophoricity, relatively low melting point $\left(1132{ }^{\circ} \mathrm{C}\right)$, and availability. During previous military conflicts such as the First Gulf War in 1991, the conflict in Bosnia and Herzegovina in 1995, and the Serbia/Kosovo conflict in 1999, hundreds of tons of DU were fired from A-10 antitank aircrafts by the NATO airforce. ${ }^{1,2}$ These $30 \mathrm{~mm}$ antitank ammunition rounds consist of a metallic DU penetrator dart in conical form with a base radius of $0.8 \mathrm{~cm}$, a length of $9.5 \mathrm{~cm}$ and a mass of $\sim 292 \mathrm{~g}$, ${ }^{3}$ usually alloyed with $\sim 0.75$ wt $\%$ of titanium to improve hardness, and embedded in an aluminum casing. ${ }^{2}$ When a penetrator hits a hard object (e.g., an armored vehicle), part of the DU is volatilized and the mixture of DU vapor and air explodes with thermobaric effects. DU dust (particle size $<5 \mu \mathrm{m}$ ) may form and be dispersed quickly in the environment. ${ }^{4}$ Although these DU aerosols are very mobile in the atmosphere, the majority of the DU remains in the local surface environment. This is because most (>90\%) penetrators miss their target and hit soft materials such as soil, ${ }^{5,6}$ precluding the production of significant DU dust. Because uranium is in a metallic form, these penetrators corrode with time. According to Handley-Sidhu et al., ${ }^{7}$ the corrosion of metallic DU takes place in two steps: (i) the oxidation of zerovalent $\mathrm{U}$ metal to $\mathrm{U}(\mathrm{IV})$ oxide, uraninite; (ii) oxidation of $\mathrm{U}(\mathrm{IV})$ oxide to $\mathrm{U}(\mathrm{VI})$ minerals. The exact processes involved in the corrosion of DU penetrators depend on the (geo)chemical and physical properties of the environment in which the penetrators reside, including $\mathrm{pH}$, redox potential (Eh), soil chemical composition, nature and concentrations of organic and inorganic solutes in soil pore water, and water saturation conditions. ${ }^{7,8}$ The $U$ minerals resulting from the corrosion process control $U$ solubility and thus its rate of release into the surrounding soil. The latter is of great concern as $U$ released from thousands of penetrators scattered around the countryside could potentially migrate

\section{Received: July 26, 2016}

Revised: October 16, 2016

Accepted: October 21, 2016

Published: October 21, 2016 
through the vadose zone and contaminate the underlying aquifer(s). Characterization of DU corrosion can thus provide invaluable information to model $U$ release during and after corrosion and has direct environmental implications for DUimpacted regions. Previous studies of corrosion of DU metal have focused on particulate DU released from firing shells and their impact on hard objects. For example, DU particles corroded in soil from Kosovo ${ }^{9,10}$ and Kuwait, ${ }^{10,11}$ or firing ranges in the U.K. ${ }^{12-14}$ and the U.S. ${ }^{15}$ were investigated using synchrotron-based X-ray microanalyses and/or electron microscopy. The resulting $\mathrm{U}$ minerals varied from metallic $\mathrm{U}$, $\mathrm{UO}_{2}, \mathrm{U}_{3} \mathrm{O}_{7}, \mathrm{U}_{3} \mathrm{O}_{8}$, to highly oxidized minerals such as schoepite and metaschoepite, depending on the mechanism of production of the particles (due to penetrator firing or impact on a hard target), and environmental conditions. Other studies also investigated $\mathrm{U}$ mineralogy of corroded DU bulk metal. For example, in laboratory microcosms, DU metal coupons cut from penetrators corroded in sandy soil, ${ }^{16}$ estuarine sediment ${ }^{17}$ or silty-loam soil ${ }^{18}$ for about 500 days. The results indicated that DU metal mainly corroded to metaschoepite in unsaturated sandy and silty-loam soils, whereas uraninite formed in suboxic/anoxic estuarine sediment. Using full penetrators embedded in laboratory columns for 3 years, Schimmack et al. ${ }^{19}$ determined the rate of $U$ corrosion and leaching, but unfortunately, a detailed characterization of the $U$ minerals produced on the surface of the penetrators was not performed.

The bulk of DU material used during previous conflicts remains in penetrator form, which (if not removed) completely corrodes in surface environments after about 25 years. ${ }^{3}$ Thus, in order to constrain the fate of bulk DU from penetrators, it is important to characterize the DU corrosion products formed under field conditions: (i) from intact DU penetrators, (ii) with a period of corrosion up to 25 years, and (iii) in soil of a postconflict region. To our knowledge, none of the previous studies in the literature were able to combine these conditions. Here, we aim to fill this knowledge gap.

The United Nations Environment Program (UNEP) and Spiez Laboratory (Switzerland) conducted field investigations in postconflict regions in Europe, ${ }^{3,20,21}$ and recovered corroded penetrators that were made available to our team. We obtained and characterized corrosion products formed from two intact DU penetrators that were corroded in situ in soils in Bosnia and Herzegovina for over seven years. ${ }^{3}$ The results show that the two penetrators extensively corroded into uranyl minerals, that is, metaschoepite $\left(\mathrm{UO}_{3}\left(\mathrm{H}_{2} \mathrm{O}\right)_{2}\right.$, a uranium trioxide dihydrate), studtite $\left(\left(\mathrm{UO}_{2}\right) \mathrm{O}_{2}\left(\mathrm{H}_{2} \mathrm{O}\right)_{2} \cdot 2\left(\mathrm{H}_{2} \mathrm{O}\right)\right.$, a uranyl peroxide tetrahydrate), or becquerelite $\left(\mathrm{Ca}\left(\mathrm{UO}_{2}\right)_{6} \mathrm{O}_{4}(\mathrm{OH})_{6}\right.$. $8\left(\mathrm{H}_{2} \mathrm{O}\right)$, a calcium uranyl oxide hydroxide octahydrate), with a corrosion rate comparable to previous laboratory studies on corrosion of bulk DU metal in aerobic environments. This is the first time that studtite and becquerelite are reported as components of DU corrosion products, probably due to the long-term incubations under field conditions in the present study. Furthermore, the results also demonstrate that the varying $U$ mineralogy is controlled by the geochemical conditions extant at the locations where the two penetrators corroded. Overall, we showcase the complexity of DU corrosion products and provide valuable insight into the fate of bulk DU metal corroded in postconflict areas.

\section{MATERIALS AND METHODS}

Sampling. The sampling campaign took place in Bosnia and Herzegovina between October 12 and 24, 2002 and was performed by UNEP and Spiez Laboratory. The "HP" penetrator was obtained from grassland near the Han Pijesak Artillery Storage and Barracks, and it was found buried in about 6-10 cm of soil (Figure S1). The DU corrosion products of this penetrator are referred to as "DUCP-HP", and it was named "NUC-02-028-401" in the UNEP report. ${ }^{3}$ The "Hz" penetrator was collected from a cobblestone yard near the center of the Hadzici Tank Repair Facility, and was found embedded in the soil-cement mixture between two cobblestones (Figure S1). The corrosion products of this penetrator are referred to as "DUCP-Hz", and it was named "NUC-02024-401" in the UNEP report. ${ }^{3}$ The two penetrators with their corrosion material were transported to Spiez Laboratory in Switzerland, carefully handled in order to avoid contamination, and weighed directly after unpacking. The samples were then cleaned mechanically by scraping the penetrators with a scalpel to collect the corrosion product, along with associated soil material. For the $\mathrm{Hz}$ penetrator, the corrosion products were divided into three parts. The inner part in contact with the remaining U metal is referred to as "DUCP-Hz-in", the outer part in contact with the surrounding soil is referred to as "DUCP-Hz-out", and the intermediate part in-between is referred to as "DUCP-Hz-mid". However, for the HP penetrator, all corrosion material from the three layers was mixed and homogenized into one sample, which is referred to as "DUCP-HP". Corrosion material associated with the surface of the penetrators was dissolved using $5 \mathrm{~mol} / \mathrm{L} \mathrm{HNO}_{3}$ in an ultrasonic bath, followed by washing with water and ethanol. The remaining DU metal from the penetrators were air-dried and then weighed. Details of sampling the penetrators and associated corrosion products from the field are given in the UNEP report. ${ }^{3}$

Soil samples were collected from the immediate vicinity of the penetrators. At the location of the HP penetrator, a soil column from the surface to $60 \mathrm{~cm}$ depth was collected. As DU migration in the soil was previously investigated, ${ }^{3}$ only three soil layers were selected here for further chemical and mineralogical analyses: above the penetrator at $0-5 \mathrm{~cm}$ in depth (referred to as "Soil-HP 0-5 cm"), around the penetrator at 6-10 cm ("Soil-HP 6-10 cm") and below the penetrator at $30-35 \mathrm{~cm}$ ("Soil-HP $30-35 \mathrm{~cm}$ "). For the $\mathrm{Hz}$ penetrator, two dark sandy soil samples were obtained from the edge of the cobblestone yard, and are referred to as "Soil-Hz-1" and "Soil-Hz-2". The soil samples were transported to Spiez Laboratory in Switzerland and dried at $40{ }^{\circ} \mathrm{C}$ in air until a constant weight was reached. They were then crushed, sieved $(2 \mathrm{~mm} / \mathrm{mesh} 10)$ and homogenized. Details of soil sample collection are available in the UNEP report. ${ }^{3}$

Chemical Analyses. DUCP and soil samples were fully dissolved using a three-step microwave digestion procedure with a high performance microwave (Microwave Laboratory Systems). Dried and homogenized sample $(100 \mathrm{mg})$ was mixed with $4 \mathrm{~mL}$ of $\mathrm{HNO}_{3}(65 \%)$ and $4 \mathrm{~mL}$ of $\mathrm{H}_{2} \mathrm{O}_{2}$ and the first microwave digestion step (all steps were carried out at $100{ }^{\circ} \mathrm{C}$ ) was started. Subsequently, the second step involved the addition of $2 \mathrm{~mL}$ of $\mathrm{HF}(48 \%)$, and the third step, the addition of $20 \mathrm{~mL}$ of $\mathrm{H}_{3} \mathrm{BO}_{3}(4.5 \%)$. The final extract was diluted with Milli-Q water to $100 \mathrm{~mL}$ and analyzed using ICP- 
OES (inductively coupled plasma optical emission spectrometry) for elemental composition.

X-ray Diffraction (XRD). Powder XRD measurements were performed on finely ground dry powder samples with $\mathrm{CuKa}$ $(8.048 \mathrm{keV}$, wavelength $=1.542 \AA)$ radiation on a Bruker D8 ADVANCE diffractometer mounted in Debye-Scherrer configuration. Data were recorded in the continuous-scan mode in the $5-60^{\circ} 2 \theta$ range with a step of $0.020^{\circ}$.

Electron Microscopy. Scanning electron microscopy (SEM) observation was conducted using a Carl Zeiss Merlin microscope with GEMINI II column at $1 \mathrm{kV}$ at CIME (Interdisciplinary center for electron microscopy) of EPFL. SEM-EDS data were obtained at $10 \mathrm{kV}$. Transmission electron microscopy (TEM) observation was conducted at CIME of EPFL. Finely ground dry sediment powder was loaded onto Ccoated TEM grids. The morphology and phase composition were studied by high-resolution TEM (HRTEM) and selected area electron diffraction (SAED) on an FEI Talos microscope at $200 \mathrm{kV}$. Phase identification was performed by analyzing SAED patterns using the JEMS software (www.jems-saas.ch). The structural data was obtained from the Inorganic Crystal Structure Database (ICSD), FIZ Karlsruhe, Germany and NIST, U.S. Department of Commerce, 2013.

X-ray Absorption Spectroscopy (XAS). Uranium $\mathrm{L}_{\mathrm{III}}{ }^{-}$ edge $(17.166 \mathrm{keV})$ XANES and EXAFS data of the DUCP samples and model compounds were obtained at the Core EXAFS beamline (B18) of Diamond Light Source (DLS). The samples were diluted in an appropriate amount of fructose to obtain an absorption step of 1-2 and then compressed into a pellet for analysis. Data were collected in transmission mode at liquid $\mathrm{N}_{2}$ temperatures $(\sim 77 \mathrm{~K})$. The $\mathrm{Si}(111)$ double-crystal monochromator was used in channel-cut mode. The spectra were collected with $I_{0}, I_{1}$, and $I_{2}$ signals using ionization chambers. Energy was calibrated by using double-transmission setup in which a uranium $\mathrm{L}_{\mathrm{III}}$-edge spectrum of the sample and that of Y metal foil reference sample (first inflection point at 17 $038 \mathrm{eV}$ ) placed between $I_{1}$ and $I_{2}$ were simultaneously recorded. Two to four EXAFS scans were averaged for each sample in order to obtain an adequate signal-to-noise ratio to $k$ $=12 \AA^{-1}$. Athena of the IFEFFIT program package ${ }^{22}$ was used for normalization and background removal. The EXAFS oscillations were extracted from raw spectra by standard methods including a spline approximation for the atomic background. The Fourier transform (FT) peaks are shifted to lower values, $R+\Delta R$, relative to the true near-neighbor distances, $R$, due to the phase shift of the electron wave in the adjacent atomic potentials. This $\Delta R$ shift is considered as a variable during shell fitting. The linear combination fitting (LCF) of the data were conducted in $\mathrm{k}=3-12 \AA^{-1}$ of the EXAFS signals. Model compounds used for LCF consisted of three uranyl minerals: metaschoepite, $\mathrm{UO}_{3}\left(\mathrm{H}_{2} \mathrm{O}\right)_{2}$; becquerelite, $\mathrm{Ca}\left(\mathrm{UO}_{2}\right)_{6} \mathrm{O}_{4}(\mathrm{OH})_{6} \cdot 8\left(\mathrm{H}_{2} \mathrm{O}\right)$; and studtite $\left(\mathrm{UO}_{2}\right)$ $\mathrm{O}_{2}\left(\mathrm{H}_{2} \mathrm{O}\right)_{2} \cdot 2\left(\mathrm{H}_{2} \mathrm{O}\right)$ (Figure $\mathrm{S} 2$ ). Synthetic metaschoepite and natural becquerelite from Shinkolobwé, Democratic Republic of the Congo were obtained from the Mineral Collection of the Musée Cantonal de Géologie of the Canton of Vaud in Switzerland. Studtite was synthesized at EPFL following the protocol published by Ulrich et $\mathrm{al}^{23}$ The powder XRD pattern of the synthetic studtite is shown in Figure S3.

\section{RESULTS AND DISCUSSION}

Characterization of Soil in the Vicinity of Corroded

Penetrators. The soil samples collected in the vicinity of the penetrators were characterized chemically and mineralogically. For the HP penetrator, the chemical composition of the soil layers above the penetrator at $0-5 \mathrm{~cm}$ (Soil-HP $0-5 \mathrm{~cm}$ ), around the penetrator at $6-10 \mathrm{~cm}$ (Soil-HP $6-10 \mathrm{~cm}$ ) and 25 $\mathrm{cm}$ below the penetrator at $30-35 \mathrm{~cm}$ (Soil-HP $30-35 \mathrm{~cm}$ ) is shown in Table S1. Si, Al, and $\mathrm{Fe}$ are major elements and their concentration ( $7.8 \%$ to $11.8 \%, 2.4 \%$ to $2.9 \%$, and $2.5 \%$ to $3.4 \%$, respectively) is similar in all three soils. Soil-HP $0-5 \mathrm{~cm}$ and 6-10 cm samples contain much higher amounts of organic matter $($ TOC $=4.7-6.8 \%)$ than Soil-HP $30-35 \mathrm{~cm}(1.7 \%)$, probably because the former two correspond to the surface organic (horizon L) and organic-rich silty-sandy layers (horizon A), whereas Soil-HP $30-35 \mathrm{~cm}$ corresponds to a silty-sandy layer with coarsening calcareous clastic content (horizon $\mathrm{B}_{\mathrm{S} 2}$ ). ${ }^{3}$ The full soil profile description is reported in Figure D.2 of the UNEP report. ${ }^{3} \mathrm{U}$ was readily detectable in Soil-HP $0-5 \mathrm{~cm}$ and Soil-HP $6-10 \mathrm{~cm}$ and the measured concentrations $(0.3 \%$ and $4.0 \mathrm{wt} \%$, respectively) were similar to the values reported in Table D.5 of the UNEP report $(0.23 \% \pm 0.05 \%$ and $4.5 \% \pm$ $0.1 \%$, respectively). ${ }^{3}$ The background $U$ concentration values in soils of the investigated locations are $0.00013-0.00048 \%{ }^{3}$ Thus, heavy DU contamination in the soil layers adjacent to the penetrator is evident. For Soil-HP $30-35 \mathrm{~cm}$, U was not detectable in the present study using ICP-OES, but the $U$ concentration was previously determined to be $5.8 \pm 0.2 \mathrm{ppm}$ and DU represents $45 \%$ of this total $\mathrm{U}$, as was determined from $\mathrm{U}$ isotopic composition obtained using ICP-MS (Inductively coupled plasma mass spectrometry). ${ }^{3}$ No evidence of contamination above natural $\mathrm{U}$ levels was detected for soil samples below $40 \mathrm{~cm}$ after over 7 years of corrosion of the penetrator in situ. ${ }^{3}$ Powder X-ray diffraction (XRD) analysis on the three soil samples shows that they possess similar mineralogy, with albite, quartz, mica and kaolinite as the detectable phases (Figure S4), and this result is consistent with their chemical composition.

For the $\mathrm{Hz}$ penetrator, the composition of the surface soil samples soil-Hz-1 and soil-Hz-2 is different from that of HP soils, as the former have a higher organic matter content (8.9$10.8 \%)$, higher calcium and magnesium content $(\mathrm{Ca}=8.1-$ $10.2 \% ; \mathrm{Mg}=3.0-3.8 \%)$, but a lower $\mathrm{Si}$ content $(5.2-5.3 \%)$ (Table S1). This is consistent with the XRD results showing that the two soil samples contain a significant amount of calcite and dolomite, together with albite, quartz, and mica (Figure S4). The presence of calcite and dolomite is most likely due to the cement used to build the compact base underlying the cobblestone pavement at this location, which will be discussed in detail later. Moreover, the similarity between the two soils suggests that the soil material in-between cobblestones in the cobblestone yard is relatively homogeneous. The $U$ concentration was determined to be $12.6 \pm 0.2 \mathrm{ppm}$ and $32.1 \pm 0.7$ ppm, and DU to represent $87 \%$ and $94 \%$ of this total U, respectively (Table D.2 in the UNEP report $^{3}$ ).

Corrosion Rate of the DU Penetrators. Both penetrators were heavily corroded during their 7-year exposure to environmental conditions (Figure S1). A thick layer of yellow and dark-greenish corrosion products formed on the surface of the penetrators and pits and cracks were observed (Figure $S 1 c, d)$. Based on the initial and remaining mass of the penetrators obtained from the UNEP report, ${ }^{3}$ the corrosion rate of the "Hz" penetrator is more rapid than that of the HP penetrator with a greater loss of metallic $\mathrm{U}$ (93.20 g vs $79.27 \mathrm{~g}$ ). Thus, assuming a constant corrosion rate, it would take roughly $22-26$ years for complete corrosion of the penetrators, which is 


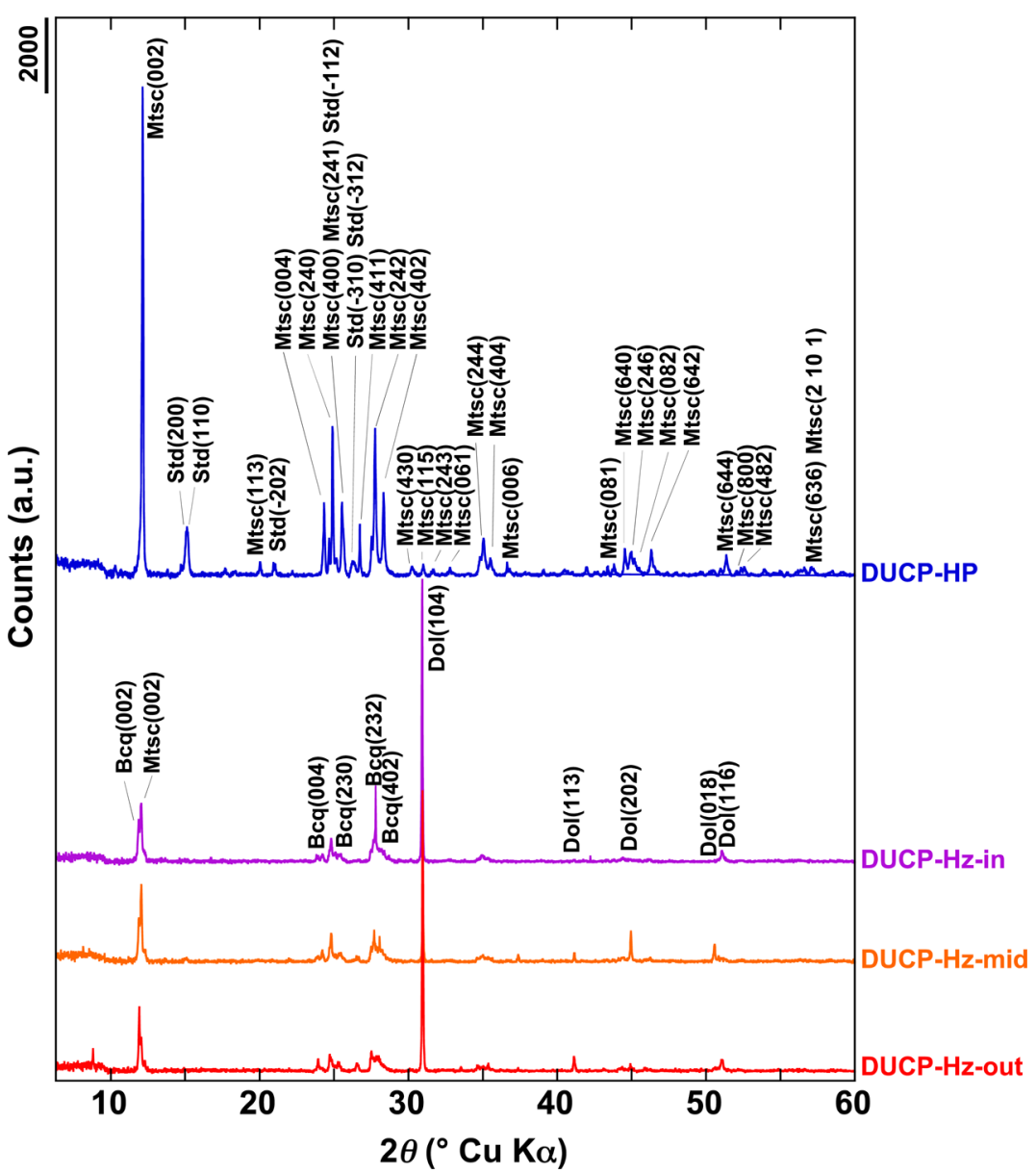

Figure 1. Powder X-ray diffraction (XRD) patterns of the depleted uranium corrosion products (DUCP) samples. The wavelength of the incident Xray beam is $1.542 \AA(\mathrm{Cu} \mathrm{K} \alpha)$. Note: Mtsc-metaschoepite, Std-studtite, Bcq-becquerelite, Dol-dolomite.
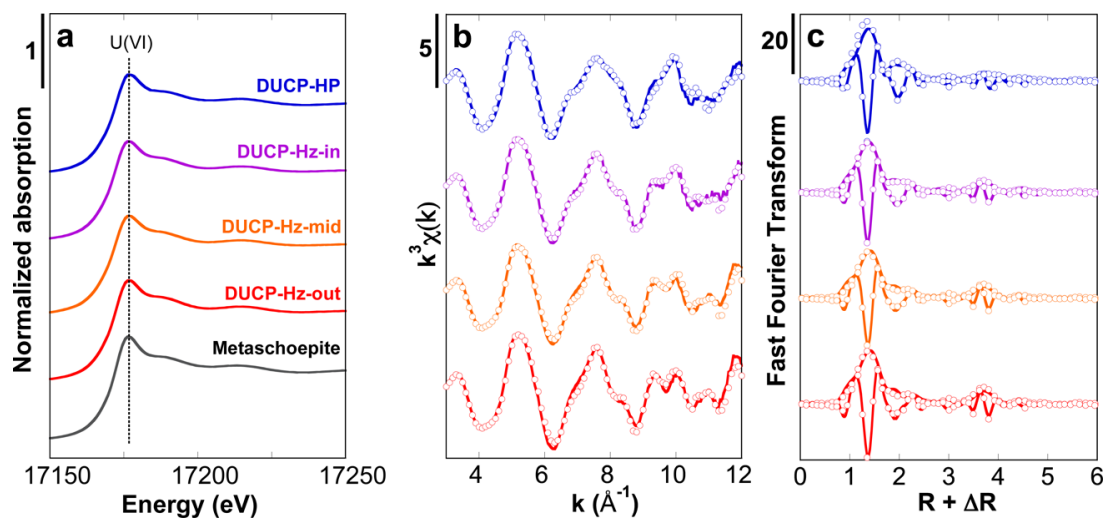

Figure 2. U L ${ }^{\mathrm{III}}$-edge XAS data collected at $77 \mathrm{~K}$ for the depleted uranium corrosion products (DUCP) samples and results of linear combination fit (LCF). Experimental and calculated curves are plotted as solid and dotted lines, respectively. (a) Normalized XANES spectra. (b) Unfiltered EXAFS $k^{3} \chi(k)$ functions. (c) Fourier transform (FT) of unfiltered $k^{3} \chi(k)$ functions in the $k$ range of $3-12 \AA^{-1}$. The spectra of the model compounds used in LCF are shown in Figure S2 and the fitting results are reported in Table S3.

consistent with a previous estimation. ${ }^{3}$ Using the size information on penetrators reported by Bleise et al., ${ }^{2}$ it is roughly estimated that the corrosion rate of the "HP" and " $\mathrm{Hz}$ " penetrators is $0.22 \pm 0.05$ and $0.26 \pm 0.05 \mathrm{~g} \mathrm{~cm}^{-2} \mathrm{yr}^{-1}$, respectively (Table S2). These values fall in the range of the corrosion rates reported in laboratory column ${ }^{19}$ and micro$\operatorname{cosm}^{16,18}$ studies with unsaturated soils $\left(0.1-0.5 \mathrm{~g} \mathrm{~cm}^{-2} \mathrm{yr}^{-1}\right)$, which are much higher than that of anaerobic saturated sediment (about $0.056 \mathrm{~g} \mathrm{~cm}^{-2} \mathrm{yr}^{-1}$ ). ${ }^{17}$ This confirms that laboratory studies can reproduce DU penetrator corrosion rates relevant to environmental conditions.

Characterization on DUCP-HP: Evidence of Studtite.

The corrosion products DUCP-HP are rich in U (73.0 wt \%) and also contains $\mathrm{Si}(0.9 \%), \mathrm{Ti}(0.7 \%)$ and trace amounts of $\mathrm{Al}$, $\mathrm{Ca}, \mathrm{Fe}, \mathrm{Mg}, \mathrm{Mn}$ and $\mathrm{Zn}$ (Table S1). $\mathrm{U}$ and $\mathrm{Ti}$ are alloyed to manufacture penetrators, and $\mathrm{Si}, \mathrm{Al}, \mathrm{Ca}, \mathrm{Fe}, \mathrm{Mg}, \mathrm{Mn}$, and $\mathrm{Zn}$ are commonly found in soil. Powder X-ray diffraction (XRD) analysis of DUCP-HP shows that it contains mainly 
metaschoepite (Figure 1). Studtite is also present as a minor component with five main Bragg reflection peaks (respective $d$ spacings: $5.88,5.83,4.21,3.38$, and $3.36 \AA)^{24}$ identified in the diffraction pattern. No other mineral phase could match all five diffraction peaks. U L $\mathrm{L}^{\mathrm{III}}$-edge X-ray absorption spectroscopy (XAS) data are collected and analyzed using linear combination fitting (LCF) with the help of model spectra of metaschoepite and studtite standards to determine the proportion of these two uranyl minerals in the sample (Figure 2; Table S3). U quantitative speciation in the sample is then calculated using the $U$ concentration and LCF speciation proportions (Figure 3 ), and the results show that nearly 100 wt $\%$ of the DUCP-HP

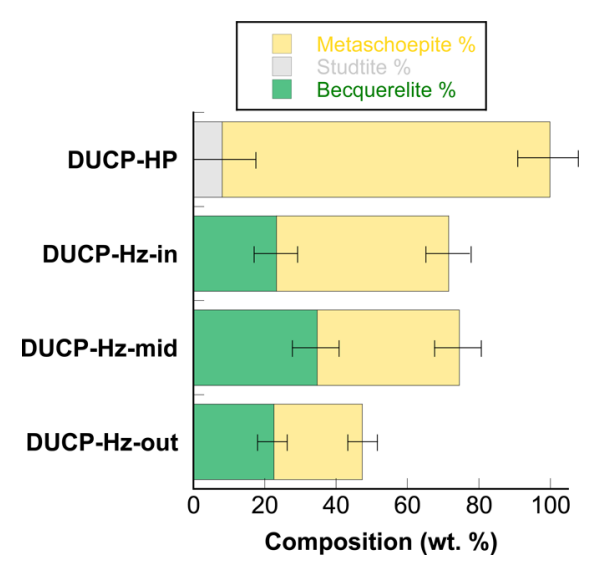

Figure 3. Uranium quantitative speciation in the depleted uranium corrosion products (DUCP) samples. The results (and its uncertainties) are calculated by multiplying $U$ concentration in DUCP samples (Table S1), the fractions of $U$ of metaschoepite, studtite and becquerelite (Table S3) obtained by LCF of U L ${ }^{\text {III-edge }}$ EXAFS data (Figure 2), and the mass fractions of $U$ in the chemical formula of metaschoepite, studtite, and becquerelite.

sample is composed of uranyl minerals, with $(92 \pm 9) \%$ as metaschoepite and $(8 \pm 10) \%$ as studtite. The morphology of U-rich particles in the sample is analyzed using scanning electron microscopy (SEM). The sample is mainly composed of plate-like or polygon-like metaschoepite particles with a size of a few 10s of micrometers (Figure 4a,b). But nanoparticles associated with micrometer-scale particles are also observed (Figure $4 c, d$ ). It worth noting that some of the micrometerscale particles carry marks of erosion, and some of them are acicular in shape (Figure 4d). These observed morphologies are in line with those reported in the literature for metaschoepite/ schoepite. ${ }^{25,26}$ But the acicular morphology is also consistent with studtite particles previously observed using SEM. ${ }^{27,28}$ As SEM observation is not capable of differentiating between the two uranyl minerals, we tried transmission electron microscopy (TEM). However, all U-rich particles analyzed using selected area electron diffraction (SAED) show a very fast structural transformation under the TEM beam, which consists of the amorphization of the original crystalline particles followed by the formation of nanouraninite (Figure S5). The occurrence of nanouraninite is in direct contradiction with the XAS and XRD results, which also suggests that the uraninite nanoparticles form during TEM observation. We propose that this is probably due to fast dehydration and collapse of the uranyl hydrates followed by reduction of $\mathrm{U}(\mathrm{VI})$ to $\mathrm{U}(\mathrm{IV})$ under the electron beam, and the same artificial process due to ionizing radiation was previously reported for uranyl hydrate minerals such as studtite, ${ }^{29}$ metastudtite ${ }^{29}$ and soddyite. ${ }^{30}$ We therefore conclude that TEM observation of the corrosion products is not reliable.

It is not surprising that metaschoepite is the main component of this DUCP, as it was commonly found as a product of DU weathering in oxic environments. ${ }^{7}$ It usually forms via partial dehydration of schoepite and reorganization of the water molecules between uranyl sheets. ${ }^{27,31,32}$ For the minor component, studtite, although its calculated proportion $(8 \%)$ is lower than the estimated XAS quantification uncertainty (10\%), the results of XRD analysis confirm its presence in the corrosion product, as several Bragg reflection peaks of this peroxide mineral are clearly observed (Figure 1). This uranyl peroxide hydrate, ${ }^{24,27,33}$ together with its dehydrated form, metastudtite, are the only two peroxidecontaining minerals found in nature. It precipitates following the reaction between uraninite or uranyl oxide hydrates with hydrogen peroxides $\left(\mathrm{H}_{2} \mathrm{O}_{2}\right),{ }^{34,35}$ because it is thermodynamically more stable. ${ }^{36}$ The radioactivity of natural $U$ deposits or spent nuclear fuel could generate a sufficient concentration of $\mathrm{H}_{2} \mathrm{O}_{2}$ by alpha radiolysis of water ${ }^{28,36}$ for the transformation of uranyl oxide hydrates to studtite $\left(\sim 10^{-14} \mathrm{M}\right)$. Although depleted $U$ shows a much lower radioactivity than natural $U$, the results from the present study show that a DU penetrator located in the vadose zone for over 7 years produces a sufficient amount of $\mathrm{H}_{2} \mathrm{O}_{2}$ to form studtite from metaschoepite. This is particularly true in thin water films on the surface of $U$ minerals or in the water layer trapped in between two $U$ oxide particles, because those are the local environments most likely to accumulate the relatively elevated peroxide concentrations needed for this transformation to occur. ${ }^{36}$ Moreover, studtite likely formed at the expense of metaschoepite, as erosion marks on some of the metaschoepite particles were observed (Figure 4d).

Characterization on DUCP-Hz: Evidence of Becquerelite and Influence of the Surrounding Environment. All three DUCP-Hz samples differ from DUCP-HP in chemical and mineralogical composition. The $U$ concentrations are 34.6-54.4 (in wt \%), significantly lower than that of the DUCP-HP sample. The DUCP-Hz samples also contain a greater concentration of $\mathrm{Ca}(2.6-3.0 \mathrm{wt} \%)$ and $\mathrm{Mg}(1.4-1.5$ wt \%) that those recorded for the DUCP-HP sample (Table $\mathrm{S} 1$ ), which is consistent with the results of powder XRD analysis showing evidence of dolomite and becquerelite (Figure 1). XRD data also clearly show the presence of metaschoepite (Figure 1). Becquerelite represents $1 / 3$ to $1 / 2$ of the total $U$ in the DUCP-Hz samples, whereas the remaining $U$ is in the form of metaschoepite (Figure 3). Interestingly, the concentration of $\mathrm{U}$ decreases and the proportion of becquerelite increases from the inner (DUCP-Hz-in), intermediate (DUCP-Hz-mid) to outer layer (DUCP-Hz-out) of the corrosion products (Figure 3 ), suggesting that the presence of $\mathrm{Ca}, \mathrm{Mg}$ and becquerelite is a signature of the surrounding soil. Indeed, as previously discussed, the nearby soil samples also show a high $\mathrm{Ca}$ (8.110.2 wt \%) and $\mathrm{Mg}(3.0-3.8$ wt \%) content (i.e., Soil-Hz-1 and Soil-Hz-2 in Table S1). We infer that, in the DUCP-Hz samples, becquerelite is formed from metaschoepite in the presence of $\mathrm{Ca}^{2+}$ from the soil. This mineralogical transformation is accelerated in the case of partially dehydrated metaschoepite particles. ${ }^{37}$ SEM observation of DUCP-Hz-mid shows that the U-bearing material consists of micrometer-scale aggregates of submicrometer particles (Figure 5a,b). Energydispersive X-ray spectroscopy coupled to SEM (SEM-EDS) analyses show that a part of the aggregates is devoid of 

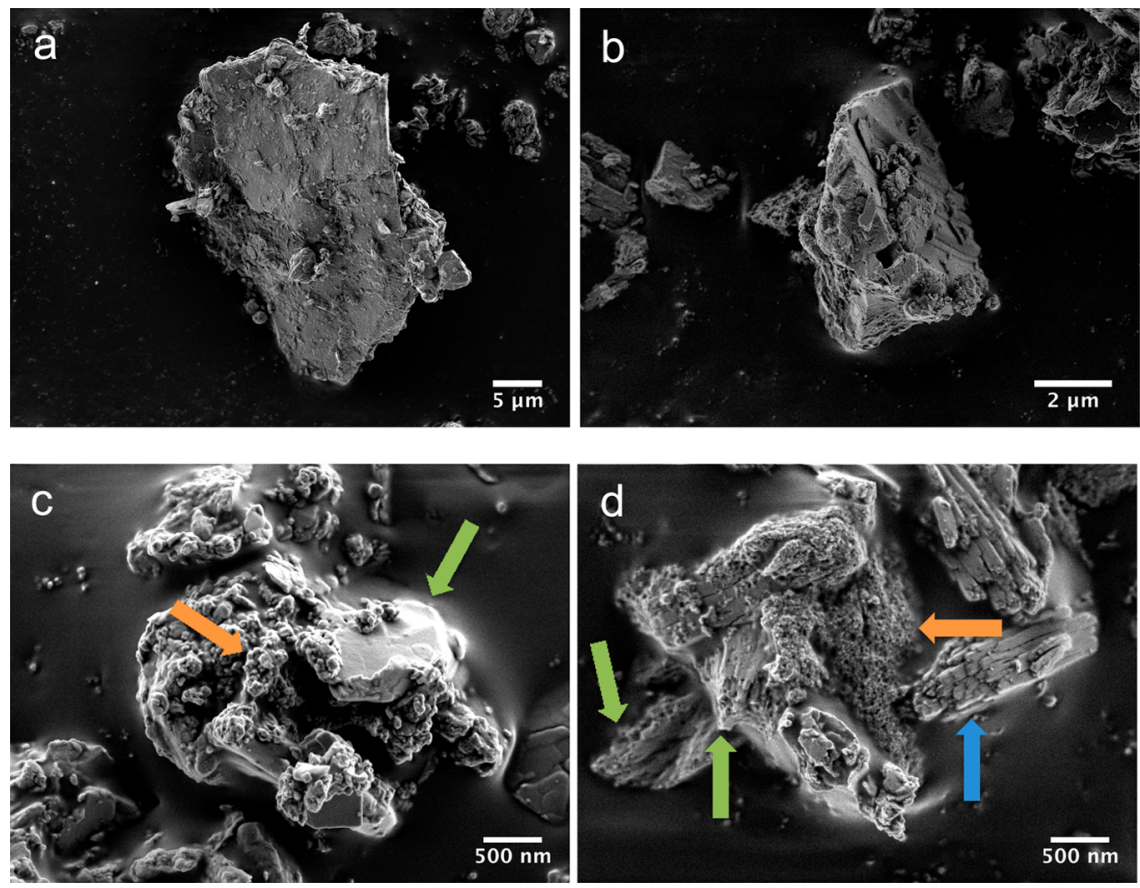

Figure 4. SEM observation of the depleted uranium corrosion products of the penetrator from Han Pijesak Artillery Storage and Barracks (DUCPHP). (a) A metaschoepite particle with plate-like morphology and a size of $\sim 25 \mu \mathrm{m}$; (b) a metaschoepite particle with polyhedron-like morphology and a size of $\sim 10 \mu \mathrm{m}$; (c) an aggregate of U-rich particles with nanoparticles (example indicated by the orange arrow) and micrometer-scale particles (example indicated by the green arrow); (d) an aggregate of U-rich particles showing nanometric ones (example indicated by the orange arrow), micrometer-scale ones with marks of erosion (example indicated by the green arrows) or with acicular-like morphology (example indicated by the blue arrow).
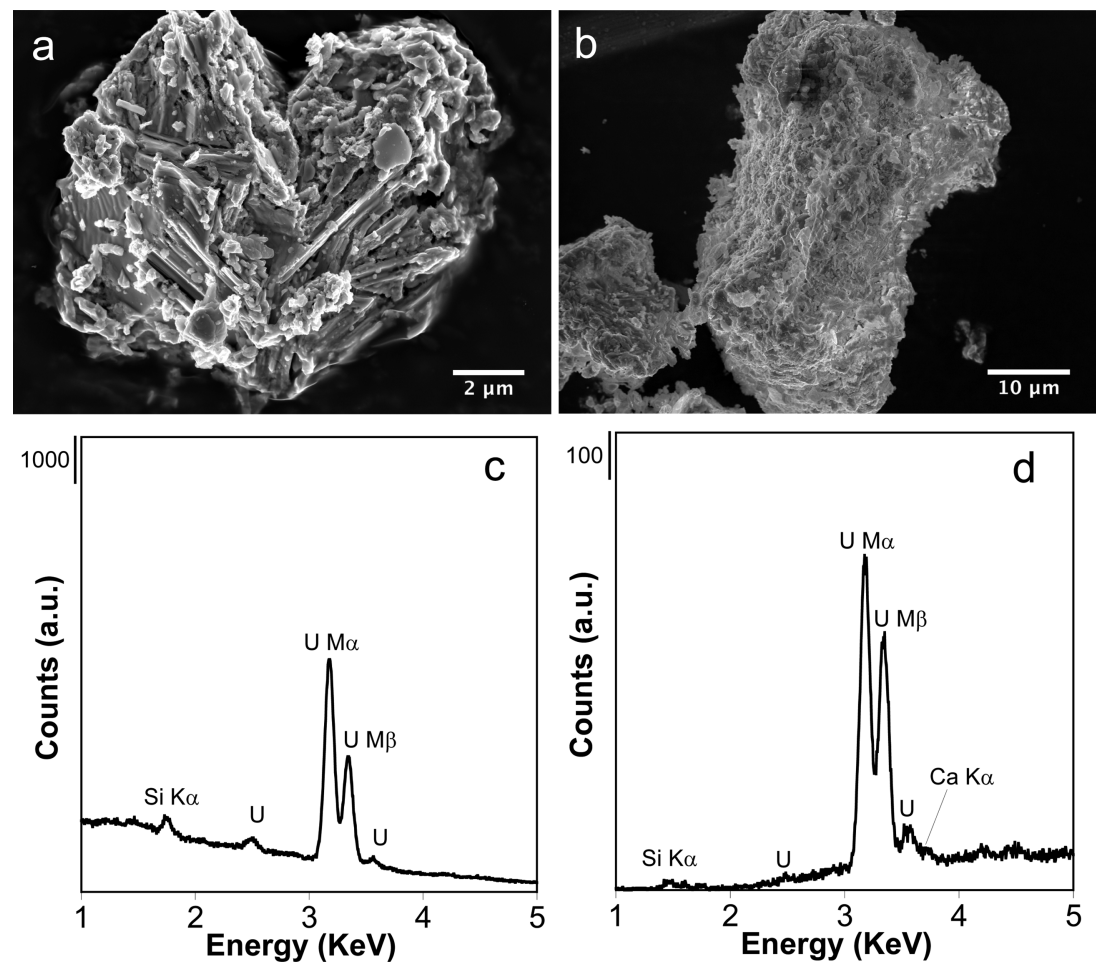

Figure 5. SEM observation data on U-bearing particles in the depleted uranium corrosion products of the penetrator from Hadzici Tank Repair Facility (DUCP-Hz-mid). (a) an aggregate of U-rich particles, probably metaschoepite; (b) an aggregate of U-rich particles, probably becquerelite; (c) the SEM-EDS spectrum obtained from the whole aggregate in (a) showing the absence of Ca, which implies metaschoepite instead of Cacontaining becquerelite; (d) the SEM-EDS spectrum obtained from the whole aggregate in (b) showing the presence of a Ca signal; the weight percentage of $U$ and Ca obtained by quantifying the spectrum $(\approx 36: 1)$ is consistent with the U:Ca mass ratio in the becquerelite chemical formula $(\approx 35.7: 1)$. 
detectable Ca (Figure 5c) while the other part contains Ca (Figure 5d). Taking into account the results of XRD and XAS analyses, the former is likely metaschoepite and the latter becquerelite.

It also worth noting that the DUCP-Hz samples contain dolomite (Figure 1) and the Soil-Hz samples contain dolomite and calcite (Figure S4), which may account for their $\mathrm{Ca}$ and $\mathrm{Mg}$ content. The two carbonate minerals, calcite and dolomite, are typically found in sedimentary rocks, however, in the present study, their formation is most likely due to the cement used to build the compact base underlying the cobblestone pavement at the location where the "Hz" penetrator was found. The exact nature of the cement used is unknown, but typical Portland cement contains up to $67 \%$ of calcium oxide $(\mathrm{CaO})$ and $5 \%$ of magnesium oxide $(\mathrm{MgO})$, and a higher $\mathrm{MgO}$ content in cement can be used in case higher expansion is needed during hydration and setting of cement. ${ }^{38,39}$ The carbonation of the cement over time with atmospheric $\mathrm{CO}_{2}$ could then lead to the formation of calcite and dolomite. For the latter carbonate mineral, it is usually found in ancient sedimentary rocks or in modern systems above $50{ }^{\circ} \mathrm{C}$, however, it was also shown that sulfate-reducing bacteria (SRB) could mediate the precipitation of this $\mathrm{Ca}-\mathrm{Mg}$ carbonate mineral at near room temperature. ${ }^{40}$ A recent study demonstrated that surfaces of biomass or organic matter with a high density of carboxylic groups could promote the abiotic precipitation of dolomite at $30{ }^{\circ} \mathrm{C}$. ${ }^{41}$ As SRBs usually require strict anoxia to thrive, they do not seem compatible with the aerobic conditions in the surface soil near the "Hz" DU penetrator. However, Soil-Hz-1 and Soil-Hz-2 harbor high organic matter contents $($ TOC $=8.9-10.8 \mathrm{wt} \%)$ (Table S1) and anoxic microenvironments conducive to SRB growth can exist within oxic sediments. ${ }^{42}$ We infer that dolomite in the DUCP-Hz samples (and the soil samples near the "Hz" DU penetrator) likely originates from the carbonation of cement and that dolomite precipitation may be mediated by carboxylic groups on the surface of organic matter of microbial necromass or SRB present in microniches in the soil.

It would be also interesting to investigate whether differences in DUCP mineralogy resulted from distinct microbial activity in the two locations where the corroded penetrators were found. Unfortunately, microbial community analyses were not carried out when the penetrators and soils samples were collected from the field in 2002. However, it was previously shown that microbial activity had limited impact on the corrosion of DU metal $^{43}$ and that corrosion was mainly driven by chemical processes controlled by the geochemical environment. ${ }^{43}$ Thus, we propose that the distinct geochemical conditions under which the two penetrators corroded are the main reason distinct DU corrosion products were obtained.

Environmental Implications. Here we report for the first time the occurrence of studtite and becquerelite as components of DU corrosion products. This is probably due to the fact that this study was able to capture the result of long-term incubations under field conditions. We thus propose that the best way to understand the fate of bulk DU material in the environment is to characterize the corrosion products of intact DU penetrators that remained under field conditions for extended periods of time.

As stated previously, more than $90 \%$ of DU material used during conflicts remains in penetrator form, and can corrode in surface environments of postconflict zones for up to 25 years. Consequently, the most likely hazard to the local population would be the dissolution of $\mathrm{U}$ from $\mathrm{DU}$ corrosion products by environmental waters and its subsequent transport through soil profile into the aquifer. Drinking water obtained from U contaminated aquifers may result in radiological and chemical toxicity. Therefore, it is important to evaluate the influence of the mineralogy of DU corrosion products on U solubility. Here we show that metaschoepite and studtite or becquerelite formed as corrosion products from two penetrators that remained in Bosnia and Herzegovina soils for more than 7 years. Their corrosion rates were comparable to those obtained from previous laboratory studies on corrosion of bulk DU metal in aerobic environments. We also show that about $8 \%$ of metaschoepite transformed into studtite in 7 years in the corrosion products of a DU penetrator (DUCP-HP), probably due to the accumulation of peroxide produced by alpha radiolysis of water molecules in thin water films on the surface of $U$ minerals. For corrosion products of the penetrator embedded in cobblestone (DUCP-Hz), $1 / 3_{3}-1 / 2$ of metaschoepite transformed to becquerelite in 7 years due to the high concentration of $\mathrm{Ca}$ in the cement. It is predictable that the fraction of studtite and becquerelite in those corrosion products would increase with time if their exposure to soil had been even longer. Therefore, by the time the DU metal in the penetrators is completely corroded (about 22-26 yr.), the fractions of becquerelite and studtite are expected to be much higher. Hence, becquerelite and studtite, together with metaschoepite, would significantly control the solubility of DU in similar environments. It is thus important to evaluate the change in $\mathrm{U}$ solubility when the transformation of metaschoepite to studtite or becquerelite occurs.

It was reported that the solubility product equilibrium constants of metaschoepite, becquerelite and studtite $\left(\mathrm{K}_{\mathrm{sp}}(\mathrm{metaschoepite}),{ }^{44} \mathrm{~K}_{\mathrm{sp}} \text { (becquerelite }\right)^{44}$, and $\left.\mathrm{K}_{\mathrm{sp}}(\text { studtite })^{36}\right)$ are $2.51-5.01 \times 10^{5}, 1.26-50.1 \times 10^{39}$, and $1.32-1.37 \times 10^{3}$, respectively, with the following dissolution reactions:

$$
\begin{aligned}
& \text { For } \mathrm{K}_{\mathrm{sp}}(\text { metaschoepite }): 2 \mathrm{H}^{+}+\mathrm{UO}_{3}\left(\mathrm{H}_{2} \mathrm{O}\right)_{2} \\
& =\mathrm{UO}_{2}{ }^{2+}+3 \mathrm{H}_{2} \mathrm{O} \\
& \text { For } \mathrm{K}_{\mathrm{sp}}(\text { becquerelite }) \text { : } \\
& \quad \begin{array}{l}
14 \mathrm{H}^{+}+\mathrm{Ca}\left(\mathrm{UO}_{2}\right)_{6} \mathrm{O}_{4}(\mathrm{OH})_{6} \cdot 8\left(\mathrm{H}_{2} \mathrm{O}\right) \\
\quad=\mathrm{Ca}^{2+}+6 \mathrm{UO}_{2}{ }^{2+}+18 \mathrm{H}_{2} \mathrm{O}
\end{array} \\
& \text { For } \mathrm{K}_{\mathrm{sp}}(\text { studtite }): 2 \mathrm{H}^{+}+\left(\mathrm{UO}_{2}\right) \mathrm{O}_{2}\left(\mathrm{H}_{2} \mathrm{O}\right)_{2} \cdot 2\left(\mathrm{H}_{2} \mathrm{O}\right) \\
& \quad=\mathrm{UO}_{2}{ }^{2+}+\mathrm{H}_{2} \mathrm{O}_{2}+4 \mathrm{H}_{2} \mathrm{O}
\end{aligned}
$$

By assuming that all components are in standard-state, $\mathrm{pH} 7$, that $\mathrm{Ca}^{2+}$ or $\mathrm{H}_{2} \mathrm{O}_{2}$ only originate from the dissolution of becquerelite or studtite, and by ignoring activity coefficients, we can calculate and obtain the $\mathrm{UO}_{2}{ }^{2+}$ concentrations in pure water in equilibrium with metaschoepite, becquerelite and studtite: $2.51-5.01 \times 10^{-9}, 3.85-6.50 \times 10^{-9}$, and $3.63-3.72 \times$ $10^{-9} \mathrm{~mol} \mathrm{~L}^{-1}$, respectively. These values are roughly similar, but because of the abundance of $\mathrm{Ca}^{2+}$ in waters in the environment and the continuous production of $\mathrm{H}_{2} \mathrm{O}_{2}$ by the alpha radiolysis, the actual dissolved $\mathrm{UO}_{2}{ }^{2+}$ concentration in equilibrium with becquerelite and studtite should be lower than the calculated values for these two minerals. For this reason, we propose that, when metaschoepite, becquerelite and/or studtite are the only predominant $\mathrm{U}$ species in DUCP, the formation of becquerelite and studtite at the expense of metaschoepite would yield a 
lower dissolved $\mathrm{UO}_{2}{ }^{2+}$ concentration than pure metaschoepite, and would thus decrease the overall solubility of $U$ from DU penetrators corroded in similar environments in postconflict areas.

\section{ASSOCIATED CONTENT}

\section{S Supporting Information}

The Supporting Information is available free of charge on the ACS Publications website at DOI: 10.1021/acs.est.6b03732.

Additional data and all experimental details (PDF)

\section{AUTHOR INFORMATION}

\section{Corresponding Author}

*E-mail: rizlan.bernier-latmani@epfl.ch.

\section{Notes}

The authors declare no competing financial interest.

\section{ACKNOWLEDGMENTS}

Financial support of this research from Spiez Laboratory is gratefully acknowledged, and we thank Béatrice Balsiger for assistance in transferring DU samples from Spiez Laboratory to EPFL. We acknowledge CEAL of EPFL for analytical support and CIME of EPFL for electron microscopy support, and we thank Elena Rossel from CEAL and Aigoul Schreier from CIME for assistance in TOC and TEM-SAED analyses, respectively. We acknowledge Diamond Light Source (Oxfordshire, UK) for access to beamline B18 (proposal number 12380) that contributed to the XAS results presented here, and we are grateful to Giannantonio Cibin and Stephen Parry for their technical assistance in XAS data acquisition. We acknowledge Kai-Uwe Ulrich for the discussion on the protocol of studtite synthesis.

\section{REFERENCES}

(1) WHO. Depleted uranium, sources, exposure and health effects, Department of protection of the human environment. In Department of Protection of the Human Environment; World Health Organization: Geneva, 2001.

(2) Bleise, A.; Danesi, P. R.; Burkart, W. Properties, use and health effects of depleted uranium (DU): a general overview. J. Environ. Radioact. 2003, 64, 93-112.

(3) UNEP, Depleted Uranium in Bosnia and Herzegovina: Post-Conflict Environmental Assessment. Revised ed.: May 2003 ed.; United Nations Environmental Programme: Switzerland, 2003.

(4) Harley, N. H.; Foulkes, E. C.; Hilborne, L. H.; Hudson, A.; Anthony, C. R., A review of the scientific literature as it pertains to Gulf war illnesses. In Depleted Uranium; RAND Corporation National Defense Research Institute: Washington, 1999; Vol. 7.

(5) CHPPM. Health Risk Assessment Consultation No. 26-MF-75500D, Depleted Uranium-Human Exposure Assessment and Health Risk Characterization in Support of the Environmental Exposure Report 'Depleted Uranium in the Gulf of the Office of the Special Assistant to the Secretary of Defense for Gulf War Illnesses, Medical Readiness, and Military Deployments (OSAGWI), OSAGWI Levels I, II, and III Scenarios; 15 September, 2000.

(6) Papastefanou, C. Depleted uranium in military conflicts and the impact on the environment. Health Phys. 2002, 83, 280-282.

(7) Handley-Sidhu, S.; Keith-Roach, M. J.; Lloyd, J. R.; Vaughan, D. J. A review of the environmental corrosion, fate and bioavailability of munitions grade depleted uranium. Sci. Total Environ. 2010, 408, $5690-5700$.

(8) Langmuir, D. Uranium solution-mineral equilibria at low temperatures with applications to sedimentary ore deposits. Geochim. Cosmochim. Acta 1978, 42, 547-569.
(9) Salbu, B.; Janssens, K.; Lind, O. C.; Proost, K.; Danesi, P. R. Oxidation states of uranium in DU particles from Kosovo. J. Environ. Radioact. 2003, 64, 167-173.

(10) Lind, O. C.; Salbu, B.; Skipperud, L.; Janssens, K.; Jaroszewicz, J.; De Nolf, W. Solid state speciation and potential bioavailability of depleted uranium particles from Kosovo and Kuwait. J. Environ. Radioact. 2009, 100, 301-307.

(11) Salbu, B.; Janssens, K.; Lind, O. C.; Proost, K.; Gijsels, L.; Danesi, P. R. Oxidation states of uranium in depleted uranium particles from Kuwait. J. Environ. Radioact. 2005, 78, 125-135.

(12) Lloyd, N. S.; Mosselmans, J. F. W.; Parrish, R. R.; Chenery, S. R. N.; Hainsworth, S. V.; Kemp, S. J. The morphologies and compositions of depleted uranium particles from an environmental case-study. Mineral. Mag. 2009, 73, 495-510.

(13) Sajih, M.; Livens, F. R.; Alvarez, R.; Morgan, M. Physicochemical characterisation of depleted uranium (DU) particles at a UK firing test range. Sci. Total Environ. 2010, 408, 5990-5996.

(14) Crean, D. E.; Livens, F. R.; Stennett, M. C.; Grolimund, D.; Borca, C. N.; Hyatt, N. C. Microanalytical X-ray Imaging of Depleted Uranium Speciation in Environmentally Aged Munitions Residues. Environ. Sci. Technol. 2014, 48, 1467-1474.

(15) Buck, B. J.; Brock, A. L.; Johnson, W. H.; Ulery, A. L. Corrosion of Depleted Uranium in an Arid Environment: Soil-Geomorphology, SEM/EDS, XRD, and Electron Microprobe Analyses. Soil Sediment Contam. 2004, 13, 545-561.

(16) Handley-Sidhu, S.; Bryan, N. D.; Worsfold, P. J.; Vaughan, D. J.; Livens, F. R.; Keith-Roach, M. J. Corrosion and transport of depleted uranium in sand-rich environments. Chemosphere 2009, 77, 14341439.

(17) Handley-Sidhu, S.; Worsfold, P. J.; Boothman, C.; Lloyd, J. R.; Alvarez, R.; Livens, F. R.; Vaughan, D. J.; Keith-Roach, M. J. Corrosion and Fate of Depleted Uranium Penetrators under Progressively Anaerobic Conditions in Estuarine Sediment. Environ. Sci. Technol. 2009, 43, 350-355.

(18) Handley-Sidhu, S.; Worsfold, P. J.; Livens, F. R.; Vaughan, D. J.; Lloyd, J. R.; Boothman, C.; Sajih, M.; Alvarez, R.; Keith-Roach, M. J. Biogeochemical Controls on the Corrosion of Depleted Uranium Alloy in Subsurface Soils. Environ. Sci. Technol. 2009, 43, 6177-6182.

(19) Schimmack, W.; Gerstmann, U.; Schultz, W.; Geipel, G. Longterm corrosion and leaching of depleted uranium (DU) in soil. Radiat. Environ. Biophys. 2007, 46, 221-227.

(20) UNEP. Depleted Uranium in Kosovo: Postconflict Environmental Assessment; United Nations Environment Programme: France, 2001.

(21) UNEP. Depleted Uranium in Serbia and Montenegro: Post-Conflict Environmental Assessment in the Federal Republic of Yugoslavia; United Nations Environmental Programme: Switzerland, 2002.

(22) Ravel, B.; Newville, M. ATHENA, ARTEMIS, HEPHAESTUS: data analysis for $\mathrm{X}$-ray absorption spectroscopy using IFEFFIT. $J$. Synchrotron Radiat. 2005, 12, 537-541.

(23) Ulrich, K. U.; Singh, A.; Schofield, E. J.; Bargar, J. R.; Veeramani, H.; Sharp, J. O.; Bernier-Latmani, R.; Giammar, D. E. Dissolution of biogenic and synthetic UO2 under varied reducing conditions. Environ. Sci. Technol. 2008, 42, 5600-5606.

(24) Burns, P. C.; Hughes, K. A. Studtite, $(\mathrm{UO} 2)(\mathrm{O}-2)(\mathrm{H} 2 \mathrm{O})(2)$ $(\mathrm{H} 2 \mathrm{O})(2)$ : The first structure of a peroxide mineral. Am. Mineral. 2003, 88, 1165-1168.

(25) Schindler, M.; Putnis, A. Crystal growth of schoepite on the (104) surface of calcite. Can. Mineral. 2004, 42, 1667-1681.

(26) Brugger, J.; Meisser, N.; Etschmann, B.; Ansermet, S.; Pring, A. Paulscherrerite from the Number 2 Workings, Mount Painter Inlier, Northern Flinders Ranges, South Australia: "Dehydrated schoepite" is a mineral after all. Am. Mineral. 2011, 96, 229-240.

(27) Walenta, K. Studtite and Its Composition. Am. Mineral. 1974, $59,166-171$.

(28) Hanson, B.; McNamara, B.; Buck, E.; Friese, J.; Jenson, E.; Krupka, K.; Arey, B. Corrosion of commercial spent nuclear fuel. 1. Formation of studtite and metastudtite. Radiochim. Acta 2005, 93, 159-168. 
(29) Rey, A.; Utsunomiya, S.; Gimenez, J.; Casas, I.; de Pablo, J.; Ewing, R. C. Stability of uranium (VI) peroxide hydrates under ionizing radiation. Am. Mineral. 2009, 94, 229-235.

(30) Sureda, R.; Casas, I.; Giménez, J.; de Pablo, J.; Quiñones, J.; Zhang, J.; Ewing, R. C. Effects of Ionizing Radiation and Temperature on Uranyl Silicates: Soddyite $(\mathrm{UO} 2) 2(\mathrm{SiO} 4)(\mathrm{H} 2 \mathrm{O}) 2$ and Uranophane $\mathrm{Ca}(\mathrm{UO} 2) 2(\mathrm{SiO} 3 \mathrm{OH}) 2 \cdot 5 \mathrm{H} 2 \mathrm{O}$. Environ. Sci. Technol. 2011, 45, $2510-2515$.

(31) Finch, R. J.; Hawthorne, F. C.; Ewing, R. C. Structural relations among schoepite, metaschoepite and "dehydrated schoepite". Canadian Mineralogist 1998, 36, 831-845.

(32) Weller, M. T.; Light, M. E.; Gelbrich, T. Structure of uranium(VI) oxide dihydrate, UO3.2H2O; synthetic meta-schoepite (UO2) $4 \mathrm{O}(\mathrm{OH}) 6.5 \mathrm{H} 2 \mathrm{O}$. Acta Crystallogr., Sect. B: Struct. Sci. 2000, 56, 577-583.

(33) Weck, P. F.; Kim, E.; Jove-Colon, C. F.; Sassani, D. C. Structures of uranyl peroxide hydrates: a first-principles study of studtite and metastudtite. Dalton Transactions 2012, 41, 9748-9752.

(34) Clarens, F.; de Pablo, J.; Díez-Pérez, I.; Casas, I.; Giménez, J.; Rovira, M. Formation of Studtite during the Oxidative Dissolution of UO2 by Hydrogen Peroxide: A SFM Study. Environ. Sci. Technol. 2004, 38, 6656-6661.

(35) Forbes, T. Z.; Horan, P.; Devine, T.; McInnis, D.; Burns, P. C. Alteration of dehydrated schoepite and soddyite to studtite, $(\mathrm{UO} 2)(\mathrm{O}-2)(\mathrm{H} 2 \mathrm{O})(2)(\mathrm{H} 2 \mathrm{O})(2)$. Am. Mineral. 2011, 96, 202-206.

(36) Kubatko, K.-A. H.; Helean, K. B.; Navrotsky, A.; Burns, P. C. Stability of Peroxide-Containing Uranyl Minerals. Science 2003, 302, 1191-1193.

(37) Sowder, A. G.; Clark, S. B.; Fjeld, R. A. The Transformation of Uranyl Oxide Hydrates: The Effect of Dehydration on Synthetic Metaschoepite and Its Alteration to Becquerelite. Environ. Sci. Technol. 1999, 33, 3552-3557.

(38) Liu, Z.; Cui, X.; Tang, M. Hydration and setting time of MgOtype expansive cement. Cem. Concr. Res. 1992, 22, 1-5.

(39) $\mathrm{Du}, \mathrm{C}$. A Review of Magnesium Oxide in Concrete. Concrete International 2005, 27, 45-50.

(40) Vasconcelos, C.; McKenzie, J. A.; Bernasconi, S.; Grujic, D.; Tiens, A. J. Microbial mediation as a possible mechanism for natural dolomite formation at low temperatures. Nature 1995, 377, 220-222.

(41) Roberts, L. C.; Hug, S. J.; Ruettimann, T.; Billah, M.; Khan, A. W.; Rahman, M. T. Arsenic removal with iron(II) and iron(III) in waters with high silicate and phosphate concentrations. Environ. Sci. Technol. 2004, 38, 307-315.

(42) Jørgensen, B. B. Bacterial sulfate reduction within reduced microniches of oxidized marine sediments. Mar. Biol. 1977, 41, 7-17. (43) Alvarez, R.; Livens, F. R.; Lloyd, J. R.; Holt, J. P.; Boothman, C.; Wincott, P.; Handley-Sidhu, S.; Keith-Roach, M.; Vaughan, D. J. Geochemical and Microbial Controls of the Decomposition of Depleted Uranium in the Environment: Experimental Studies using Soil Microorganisms. Geomicrobiol. J. 2011, 28, 457-470.

(44) Gorman-Lewis, D.; Fein, J. B.; Burns, P. C.; Szymanowski, J. E. S. Converse, J. Solubility measurements of the uranyl oxide hydrate phases metaschoepite, compreignacite, Na-compreignacite, becquerelite, and clarkeite. J. Chem. Thermodyn. 2008, 40, 980-990. 